\title{
PENGARUH TAHAPAN PROSES PELUBANGAN DAN ARAH SERAT TERHADAP KEKUATAN TARIK MATERIAL KOMPOSIT POLYESTER-PANDAN WANGI
}

\author{
Heri Sunardi, Achmad Zainuri, Agus Dwi Catur \\ Jurusan Teknik Mesin, Universitas Mataram
}

\begin{abstract}
Almost all components, both metallic and non-metallic, experience the process of splicing (joining) with other components. Metal components can be welded, bolted and riveted. However, a special non metal materials such as composites, joining can not be done by welding. One type of connection is suitable for composite materials and keeling bolt connection.

The purpose of this study was to investigate the influence of the stage of making a hole with drilling machine and a variation of the fiber direction tensile strength of fiber-reinforced composite material with at pandan wangi polyester matrix. On stage perforation process conducted by three stages with the first stage (diameter 2, then continued with a diameter of 4 and $6 \mathrm{~mm}$ ), stage II (diameter of 4 and then continued with a diameter of $6 \mathrm{~mm}$ ), and stage III (diameter $6 \mathrm{~mm}$ ). And for a variety of fiber direction using random fiber direction, the direction, and woven with 30\% fiber volume fraction.

The results of this study showed an increase in tensile strength composite material fiber reinforced polyester-pandan wangi with unidirectional fiber orientation, which contained the highest tensile strength of the composite stage I in the amount of $27.20 \mathrm{MPa}$ and a tensile strength composite lowest was at stage III amounting 13:00 MPa. In a composite material with random fiber orientation tensile strength decreased by $19.93 \%$ with the highest tensile strength found in stage I in the amount of $17.90 \mathrm{MPa}$ and the lowest tensile strength found in stage III at 8:00 MPa. And the orientation of the woven fiber tensile strength decreased by $51.09 \%$ with the highest tensile strength is found in the first stage of 17:30 MPa and the lowest tensile strength found in stage III at 6.80 $\mathrm{MPa}$.
\end{abstract}

Key Words: Tensile Strength, perforation process, Random Fiber Unidirectional Fiber, Woven Fiber.

\section{Latar Belakang}

Penggunaan material yang siap diaplikasikan sebagai komponen pada suatu struktur menuntut adanya peningkatan sifat mekanis yang tinggi. Para rekayasawan pun selalu melakukan berbagai kajian riset untuk merekayasa material baru yang memiliki sifat fisis-mekanis lebih baik, seperti bahan baru komposit. Komposit berpenguat serat merupakan jenis komposit yang paling banyak dikembangkan. (Diharjo K. \& Triyono T. : 2000)

Gibson (1994) menyimpulkan bahwa kekuatan tarik dan kekuatan impak dipengaruhi oleh fraksi volume serat,semakin tinggi fraksi volume serat maka semakin tinggi pula kekuatannya. Adanya voids pada suatu material komposit akan sangat mengurangi kekuatan material tersebut, begitu juga dengan daerah yang kaya matriks karena tidak adanya penguatan pada daerah tersebut.

Setyawan (2005) meneliti besarnya kekuatan tarik komposit serat kenaf matrik poliester jenis (UPRs) Unsaturated Polyester Resin dan $\mathrm{Vf}=20 \%$ dengan perbedaan kadar hardener $0,5 \%, 0,75 \%, 1 \%, 1,25 \%, 1,5 \%$, mendapatkan nilai berturut-turut sebesar 33,72 $\mathrm{N} / \mathrm{mm} 2,35,95 \mathrm{~N} / \mathrm{mm} 2,40,58 \mathrm{~N} / \mathrm{mm} 2,39,97$ $\mathrm{N} / \mathrm{mm} 2$, dan $33,97 \mathrm{~N} / \mathrm{mm} 2$. Jadi dapat disimpulkan pengaruh kadar hardener sebesar $1 \%$, mempunyai kekuatan tarik yang paling tinggi.

Yuliastomo (2006) melakukan pengujian kekuatan tarik komposit serat nylon penyusunan serat dengan sudut 00 dan 900 , dengan matrik polyester mempunyai nilai ratarata sebesar 9,415 $\mathrm{MPa}$, dengan modulus elastisitasnya 7532,3 MPa. Sedangkan 
kekuatan impak rata-rata adalah 0,0009 $\mathrm{J} / \mathrm{mm} 2$.

Hampir semua komponen, baik logam maupun non logam, mengalami proses penyambungan (joining) dengan komponen lain. Komponen logam dapat disambung dengan las, dibaut, dan dikeling. Namun khusus bahan non metal seperti komposit, penyambungannya tidak dapat dilakukan dengan pengelasan. Salah satu jenis sambungan yang cocok untuk bahan komposit adalah sambungan baut dan keeling (Schwartz M. : 1984). Penyambungan ini memerlukan lubang sebagai tempat dudukan baut atau keling. Daerah sekitar lubang merupakan daerah kritis terhadap awal terjadinya kegagalan.

Berdasarkan uraian tersebut di atas, maka penelitian tentang pengaruh proses pembuatan lubang dengan drilling machine terhadap kekuatan tarik material komposit polyester-pandan wangi merupakan hal yang sangat menarik untuk dikaji lebih lanjut (diteliti).

\section{Landasan Teori}

Bahan-bahan serat alam merupakan kandidat sebagai bahan penguat untuk dapat menghasilkan bahan komposit yang ringan, kuat, ramah lingkungan serta ekonomis. Alam telah banyak menyediakan kebutuhan manusia mulai dari makanan sampai bahan bangunan. Salah satunya adalah bahan-bahan serat alam.

Teknik pembuatan lubang dan variasi diameter lubang sangat menentukan kekuatan-kekuatan dari material komposit, khususnya di daerah sekitar lubang. Teknik penguatan daerah sekitar lubang dapat dilakukan dengan dua cara yaitu meminimalkan daerah yang miskin penguat (serat) dan meminimalkan kemungkinan terjadinya delaminasi. (Kuncoro Diharjo : 2011).

\section{Komposit}

Struktur material dalam bidang engineering dapat dibagi menjadi empat kategori, yaitu logam, polimer, keramik, dan komposit. Definisi tentang material komposit, yang paling umum adalah: "Komposit merupakan material gabungan yang dibuat melalui penyusunan secara sintetik dua atau lebih komponen yaitu, suatu bahan pengisi (filler) atau semacam senyawa penguat tertentu dan bahan pengikatnya (yang umumnya ada dalam jumlah dominan/matrik), yang dinamakan resin untuk mendapatkan karakteristik dan sifat-sifat tertentu" (Schwartz, 1984).

Komposit merupakan bahan yang terdiri atas serat yang diselubungi oleh matrik, biasanya berupa polimer, metal, atau keramik. Serat biasanya berupa bahan dengan kekuatan dan modulus yang tinggi yang berperan sebagai penyandang beban utama. Matrik harus menjaga serat tetap dalam lokasi dan orientasi yang dikehendaki. Matrik juga berfungsi sebagai media transfer beban antar serat, pelindung serat dari kerusakan sebelum, ketika dan setelah proses pembuatan komposit, serta melindungi dari pengaruh abrasif antar serat (IPTN, 1993).

Komponen penyusun komposit tidak saling melarutkan ataupun bergabung satu sama lain dengan sempurna, akan tetapi bertindak bersama-sama. Semua komponen serta interfasa (yang memegang peranan penting dalam mengontrol sifat-sifat komposit) yang berada diantaranya, umumnya dapat didefinisikan secara fisik. Sifat komposit secara keseluruhan tidak bisa dicapai hanya dari tiap-tiap komponen yang bertindak sendiri-sendiri (Schwardz, 1984).

Berdasarkan bentuk komponen strukturalnya, bentuk-bentuk komponen utama yang digunakan dalam material komposit dapat dibagi atas tiga kelas (Schwartz, 1984), yaitu:

1. Komposit Serat

Komposit serat (Fibricus Composite) adalah komposit yang terdiri dari serat dan matrik yang dibuat secara fabrikasi, misalnya serat ditambah resin sebagai bahan perekat. Komposit serat merupakan jenis komposit yang hanya terdiri dari satu lamina atau satu lapisan yang menggunakan penguat berupa serat. Serat yang digunakan bisa berupa glass fibers, carbon fibers, aramid fibers, dan sebagainya. Serat ini disusun secara acak (Chopped Strand Mat) maupun dengan orientasi tertentu bahkan bisa juga dalam bentuk yang lebih komplek seperti anyaman, sebagai contoh FRP (Fibrous Reinforce Plastic) plastik yang diperkuat dengan serat dan banyak digunakan, yang sering disebut fiber glass, contoh lainnya PCB (Pulp Cement Bord) semen yang diperkaya dengan serat pulp dan dicetak dalam lembaran datar atau gelombang. 
2. Komposit Partikel

$$
\text { Komposit partikel (Particulate }
$$

Composite) adalah komposit yang terdiri dari partikel dan matrik yaitu butiran. Komposit partikel mempunyai bahan penguat yang dimensinya kurang lebih sama, seperti bulat serpih, balok, serta bentuk-bentuk lainnya yang memiliki sumbu hampir sama, yang kerap disebut partikel, dan bisa terbuat dari satu atau lebih material yang dibenamkan dalam suatu matriks dengan material yang berbeda. Partikelnya bisa logam atau nonlogam, seperti halnya matrik. Adapula polimer yang mengandung partikel yang hanya dimaksudkan untuk memperbesar volume material dan bukan untuk kepentingan sebagai bahan penguat. Komposit ini biasa dinamakan komposit skeletal/bermuatan.

3. Komposit Laminat

$$
\text { Komposit laminat }
$$

(Laminated Composite), merupakan jenis komposit yang tersusun atas dua atau lebih lamina. Komposit serat dalam bentuk lamina ini yang paling banyak digunakan dalam lingkup teknologi otomotif maupun industri.

Dalam hal polimer diperkuat serat, ada zat ketiga yang disebut zat penjodoh, penggabungan atau penyerasi untuk meningkatkan sekatan antara serat dan matrik (Feldman D., 1995).

Bahan komposit pada umumnya terdiri dari dua unsur, yaitu serat (fiber) sebagai bahan pengisi dan bahan pengikat serat-serat tersebut yang disebut matrik. $\mathrm{Di}$ dalam komposit unsur utamanya adalah serat, sedangkan bahan pengikatnya menggunakan bahan polimer yang mudah dibentuk dan mempunyai daya pengikat yang tinggi.

\section{Serat}

Serat adalah bahan pengisi matrik yang digunakan untuk dapat memperbaiki sifat dan struktur matrik yang tidak dimilikinya, juga diharapkan mampu menjadi bahan penguat matrik pada komposit untuk menahan gaya yang terjadi. Dalam pembuatan komposit tata letak, arah dan panjang serat dalam matrik juga akan menentukan kekuatan mekanik komposit, dimana letak dan arah dapat mempengaruhi kinerja atau kekuatan komposit tersebut.

\section{a. Letak dan Arah Serat}

Arah serat juga mempengaruhi jumlah berat yang dapat diisikan ke dalam matrik (Hartono, dkk., 1995). Makin cermat penataannya makin banyak pemuat yang dapat dimasukkan. Pada penelitian ini menggunakan arah serat acak/random yaitu seratnya tersebar secara acak diantara matriknya. Tipe acak sering digunakan pada produksi dengan volume besar karena faktor biaya manufakturnya yang lebih murah. Arah serat sesuai dengan kekuatan maksimum dapat ditunjukan pada gambar berikut

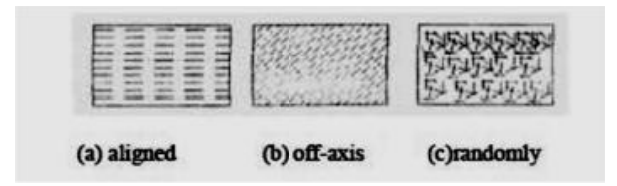

Gambar 2.1. Berbagai arah serat (sumber : Gibson, 1994)

Arah serat juga mempengaruhi jumlah berat yang dapat diisikan ke dalam matrik. Makin cermat penataannya makin banyak pemuat yang dapat dimasukkan.bila arah sejajar peluang pengisianya sampai $99 \%$, bila dwi arah peluangnya $75 \%$, dan tatanan acak atau isotropik peluang pengisianya $15-50 \%$. Pada penelitian ini menggunakan arah serat acak/random yaitu seratnya tersebar secara acak diantara matriknya. Tipe acak sering digunakan pada produksi dengan volume besar karena faktor biaya manufakturnya yang lebih murah.

b. Panjang Serat

Panjang serat dalam pembuatan komposit serat pada matrik sangat berpengaruh terhadap kekuatan. Ada 2 penggunaan serat dalam campuran komposit yaitu serat pendek dan serat panjang. Serat panjang lebih kuat dibanding serat pendek. Serat alami jika dibandingkan dengan serat sintetis mempunyai panjang dan diameter yang tidak seragam pada setiap jenisnya. Oleh karena itu panjang dan diameter sangat berpengaruh pada kekuatan maupun modulus komposit. Panjang serat berbanding diameter serat sering disebut dengan istilah aspect ratio.

\section{Matrik}

Pada dasarnya matrik adalah resin, sehingga memiliki fungsi yang sama. Resin adalah suatu material yang berbentuk cairan pada suhu ruang, atau dapat pula berupa material padatan yang dapat meleleh pada suhu di atas 2000C. Di tinjau dari jenis bahannya, matrik dapat dibedakanmenjadi tiga yaitu matrik polimer, matrik keramik, dan 
matrik metal. Matrik polimer mempunyai dua jenis berdasarkan pembuatannya yaitu polimer jenis termoset dan termoplastik. (Hartomo, 1999 : 48)

Sebagai komponen utama pembentuk komposit, dalam melakukan pemilihan terhadap matrik harus memperhatikan elongasi/batas mulur. Matrik yang digunakan sebaiknya mempunyai elongasi yang lebih besar daripada elongasi serat. Sebagai contoh jika elongasi yang dimiliki oleh serat $3 \%$, maka matrik harus mempunyai elongasi lebih dari $3 \%$. Ikatan antarmuka yang kuat antara matrik dan serat sangat diperlukan, oleh karena itu matrik harus mampu menghasilkan ikatan mekanis atau kimia dengan serat. Matrik ini juga harus cocok secara kimia dengan serat, sehingga reaksi yang tidak diinginkan tidak terjadi pada interface. Matrik dan serat sebaiknya mempunyai sifat-sifat mekanis yang saling melengkapi diantara keduanya (Gibson,1994).

\section{Daun Pandan Wangi (Pandanus Amaryllifolius)}

Menurut sentra informasi iptek (2009) Pandan wangi yang dalam bahasa latinnya Pandanus amaryllifolius Roxb, tumbuh liar di daerah tropis.

Di Indonesia terdapat dua jenis pandan yang kita kenal, yaitu pandan wangi yang sering digunakan untuk masakan serta pandan duri (pandan yang memiliki duri di tepi daunnya serta baunya tidak wangi) yang digunakan untuk pembungkus makanan. Selain digunakan untuk masakan (sebagai aroma pewangi) tanaman pandan wangi juga memiliki kegunaan yang lain.

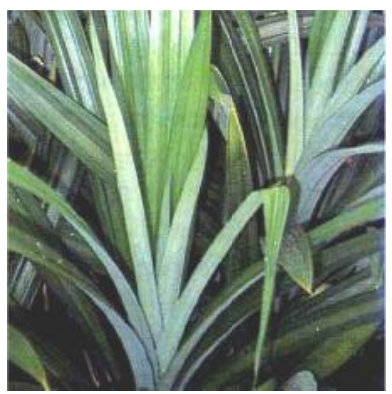

Gambar 2.2. Tanaman pandan wangi

Pemanfaatan pandan wangi selain sebagai rempah-rempah juga digunakan sebagai bahan baku pembuatan minyak wangi. Daunnya sering digunakan sebagai bahan penyedap, pewangi dan pemberi warna hijau pada masakan atau penganan.

\section{Resin Unsaturated Polyester (UP)}

Unsaturated Polyester merupakan jenis resin thermoset. Dalam kebanyakan hal ini disebut polyester saja. Karena berupa resin cair dengan viskositas yang relatif rendah, mengeras pada suhu kamar dengan penggunaan katalis tanpa menghasilkan gas sewaktu pengesetan seperti banyak resin lainnya.

Sifat resin ini adalah kaku dan rapuh. Mengenai sifat termalnya karena banyak mengandung monomer stiren, maka suhu deformasi thermal lebih rendah daripada resin thermoset lainnya dan ketahanan panas jangka panjangnya adalah kira-kira 110-1400 C. Ketahanan dingin adalah baik secara relatif. Sifat listriknya lebih baik diantara resin thermoset. Mengenai ketahanan kimianya, pada umumnya kuat terhadap asam kecuali asam pengoksid, tetapi lemah terhadap alkali. Bila dimasukkan dalam air mendidih untuk waktu yang lama (300 jam).

Tabel 2.1. Spesifikasi resin Unsaturated

\begin{tabular}{|c|c|c|c|}
\hline Item & Satuan & Catatan & Nilai Tipikal \\
\hline Berat Jenis & $\mathrm{Gr} / \mathrm{cm}^{3}$ & 1.215 & $25^{0}$ \\
\hline Kekerasan & & 40 & $\begin{array}{l}\text { Barcol GYZJ } \\
934-1\end{array}$ \\
\hline $\begin{array}{l}\text { Suhu } \\
\text { distorsi } \\
\text { panas }\end{array}$ & ${ }^{0} \mathrm{C}$ & 70 & \\
\hline \multirow{2}{*}{$\begin{array}{l}\text { Penyerapa } \\
\text { n air (suhu } \\
\text { ruangan) }\end{array}$} & $\%$ & 0.188 & 24 jam \\
\hline & $\%$ & 0.466 & 3 hari \\
\hline $\begin{array}{l}\text { Kekuatan } \\
\text { Fleksural }\end{array}$ & $\mathrm{Kg} / \mathrm{mm}^{2}$ & 9.4 & \\
\hline $\begin{array}{l}\text { Modulus } \\
\text { Fleksural }\end{array}$ & $\mathrm{Kg} / \mathrm{mm}^{2}$ & 300 & \\
\hline $\begin{array}{l}\text { Daya } \\
\text { Rentang }\end{array}$ & $\mathrm{Kg} / \mathrm{mm}^{2}$ & 5.5 & \\
\hline $\begin{array}{l}\text { Modulus } \\
\text { rentang }\end{array}$ & $\mathrm{Kg} / \mathrm{mm}^{2}$ & 300 & \\
\hline Elongasi & $\%$ & 1.6 & \\
\hline
\end{tabular}

Kemampuan terhadap cuaca sangat baik. Tahan terhadap kelembaban dan sinar ultra violet bila dibiarkan di luar, tetapi sifat tembus cahaya permukaan rusak dalam 
beberapa tahun. Secara luas digunakan untuk konstruksi sebagai bahan komposit.

Penggunaan resin jenis ini dapat dilakukan dari proses hand layup sampai dengan proses yang kompleks yaitu dengan proses mekanik. Resin ini banyak digunakan dalam aplikasi komposit pada dunia industri dengan pertimbangan harga relatif murah, curing yang cepat, warna jernih, kestabilan dimensional dan mudah penanganannya (Billmeyer, 1984). Pengesetan termal digunakan Benzoil Peroksida (BPO) sebagai katalis. Temperatur optimal adalah $80-1300 \mathrm{C}$, namun demikian kebanyakan pengesetan dingin yang digunakan. Metyl Etyl Keton Peroksida (MEKPO) digunakan sebagai katalis dan ditambahkan pada 1-2 \% (Surdia, 2001).

\section{Proses Pembuatan Lubang (Drilling Process)}

Proses pembuatan lubang bisa dilakukan untuk satu pahat saja atau dengan banyak pahat. Dalam proses produksi permesinan sebagian besar lubang dihasilkan dengan menggunakan Mesin Gurdi (Drilling Machine).

\section{a. Prinsip Dasar}

Pengeboran atau proses gurdi adalah suatu proses pengerjaan pemotongan menggunakan mata bor (twist drill) untuk menghasilkan lubang yang bulat pada material logam maupun non logam yang masih pejal atau material yang sudah berlubang. Proses gurdi adalah proses pemesinan yang paling sederhana di antara proses pemesinan yang lain. Biasanya di bengkel atau workshop proses ini dinamakan proses bor, walaupun istilah ini sebenarnya kurang tepat. Proses gurdi dimaksudkan sebagai proses pembuatan lubang bulat dengan menggunakan mata bor (twist drill). Sedangkan proses bor (boring) adalah proses meluaskan atau memperbesar lubang yang bisa dilakukan dengan batang bor (boring bar) yang tidak hanya dilakukan pada Mesin Gurdi, tetapi bisa dengan Mesin Bubut, Mesin Frais, atau Mesin Bor (Widarto 2011).

Mesin yang digunakan untuk melakukan proses gurdi adalah Mesin Gurdi/Drilling Machine. Proses pembuatan lubang bisa dilakukan untuk satu pahat saja atau dengan banyak pahat (Gambar 2.3 dan gambar 2.4).

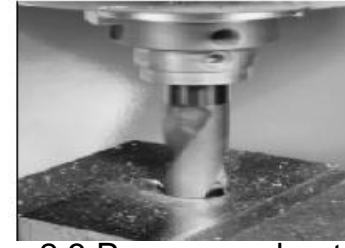

Gambar 2.3 Proses pembuatan lubang dengan Mesin Gurdi dengan satu pahat

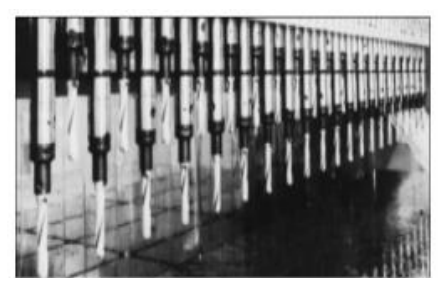

Gambar 2.4. Proses pembuatan lubang dengan Mesin Gurdi dengan banyak pahat

Tabel 2.2. Perbedaan proses drilling dan boring:

\begin{tabular}{|l|l|l|}
\hline & \multicolumn{1}{|c|}{ Drilling } & \multicolumn{1}{|c|}{ Boring } \\
\hline $\begin{array}{l}\text { Alat } \\
\text { potong }\end{array}$ & mata bor & pahat ISO 8/9 \\
\hline $\begin{array}{l}\text { Material } \\
\text { awal }\end{array}$ & Bisa pejal & $\begin{array}{l}\text { Harus sudah } \\
\text { berlubang }\end{array}$ \\
\hline $\begin{array}{l}\text { Ukuran } \\
\text { lubang }\end{array}$ & $\begin{array}{l}\text { Sama } \\
\text { dengan } \\
\text { ukuran mata } \\
\text { bor }\end{array}$ & $\begin{array}{l}\text { Lebih besar } \\
\text { dan dapat } \\
\text { diatur }\end{array}$ \\
\hline $\begin{array}{l}\text { Alat } \\
\text { pencekam }\end{array}$ & $\begin{array}{l}\text { Drill chuck, } \\
\text { sleeve }\end{array}$ & Boring head \\
\hline
\end{tabular}

b. Geometri Mata Bor (Twist Drill)

Nama-nama bagian mata bor ditunjukkan pada Gambar 2.5. Di antara bagian bagian mata bor tersebut yang paling utama adalah sudut helix (helix angle), sudut ujung (point angle/lip angle, 2Xr), dan sudut bebas (clearance angle, $\alpha$ ). Untuk bahan benda kerja yang berbeda, sudut-sudut tersebut besarnya bervariasi (Tabel 2.3).

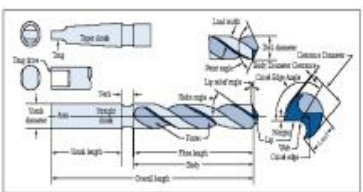

Gambar 2.5. Nama-nama bagian mata bor dengan sarung tirusnya. 


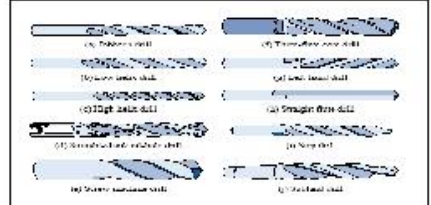

Gambar 2.6. Mata bor khusus untuk pengerjaan tertentu.

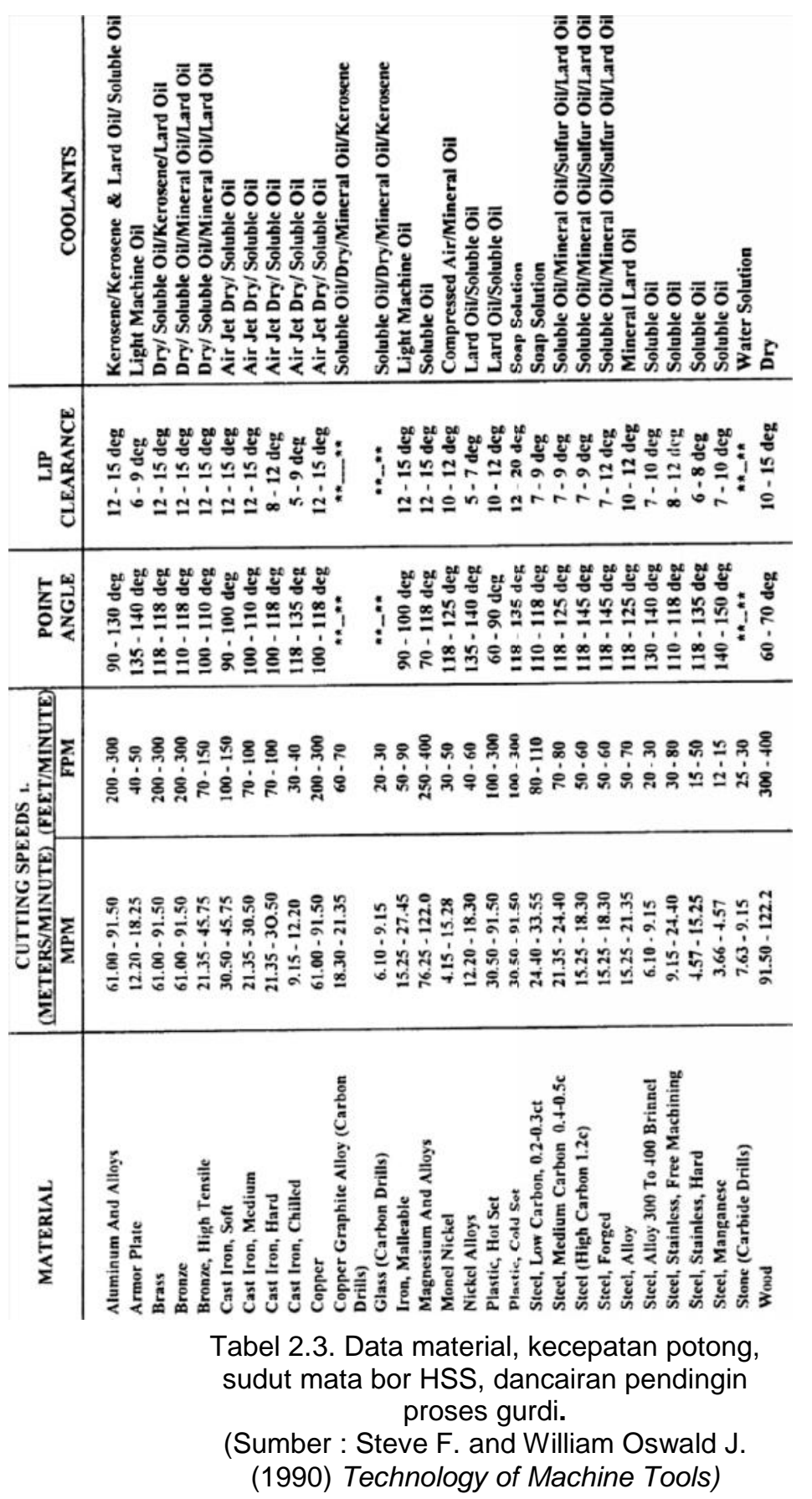

\section{METODE PENELITIAN}

Tegangan Tarik

Salah satu faktor penting yang menentukan karakteristik dari komposit adalah perbandingan matrik dan penguat/serat. Pengujian tarik dilakukan untuk mengetahui besarnya kekuatan tarik dari bahan komposit. Bahan utama penelitian ini adalah serat pandan wangi dan unsaturated polyester. Pembuatan lubang dilakukan dengan dibor, pengeboran lubang dilakukan dengan pisau bor HSS pada putaran 1420 rpm. Spesimen uji dibuat dengan tarik komposit berlubang dibuat dengan mengacu pada standar ASTM D 5766 seperti terlihat pada gambar 2.7.

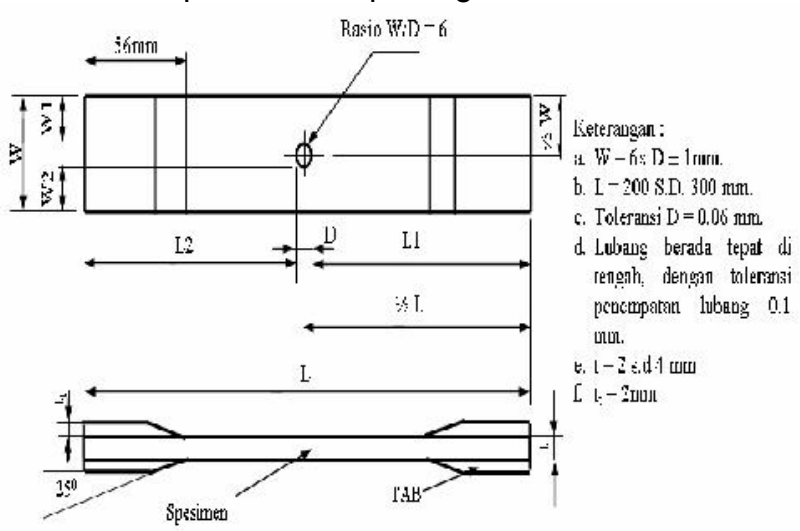

Gambar 2.7. Spesimen uji tarik komposit (ASTM D 5766)

Kekuatan tarik komposit dapat dihitung dengan persamaan Gibson, O. F. (1994) $\sigma=\frac{F_{\max }}{A}$



Keterangan:

$\sigma=$ kekuatan tarik maximum dari komposit berlubang, $\left(\mathrm{N} / \mathrm{mm}^{2}\right)$ 
$F_{\text {max }}=$ beban maximum $(\mathrm{N})$, dan

A = luas penampang komposit dengan mengabaikan adanya lubang $\left(\mathrm{mm}^{2}\right)$.

Di mana: $\quad \mathrm{A}=\mathrm{W} \times \mathrm{t}$
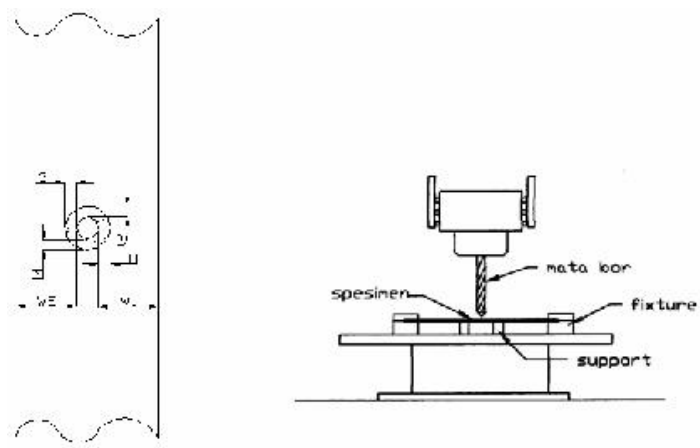

Gambar 2.8 Pengukuran delaminasi dan Proses pembuatan lubang dibor

Pengamatan permukaan patah komposit setelah uji tarik dilakukan dengan menggunakan kamera digital. Berdasarkan analisis pada gambar 2.8, maka lebar delaminasi dapat dihitung dengan persamaan:

Lebar delaminasi :

$$
I_{\text {Rata-rata }}=\frac{l 1+l 2+l 3+l 4}{4} .
$$

Jarak rata-rata dari tepi lubang ke tepi spesimen:

$$
W_{\text {Rata-rata }}=\frac{W_{1}+W_{2}}{2}
$$

Prosedur pembuatan lubang dengan pengeboran ditunjukkan pada gambar 2.9 (Steve F. and William Oswald J. : 1990)

\section{Pengujian Statistik}

Pada penelitian ini,analisis data dari hasil pengujian tarikkomposit berlubang polyester-pandan wangi menggunakan program SPSS atau Statistical Product and Service Solution untuk menggantikan analisis yang dilakukan secara manual. SPSS merupakan program analisis statistik yang mudah dioperasikan. Cara kerja SPSS dapat diterangkan sebagai berikut.

Proses pengolahan data dengan menggunakan SPSS dapat diterangkandengan menggunakan gambar dibawah ini. Proses dalam gambar tersebut dapat diterangkan sebagai berikut:

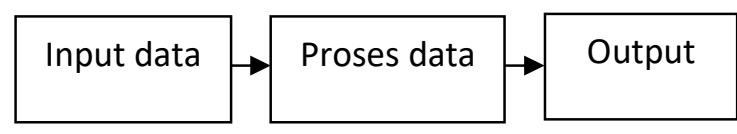

Keunggulan program SPSS ialah pemrosessan dan analisis data dapat dilakukan dengan cepat dan hasilnya akurat, sehingga dapat digunakan dalam pengambilan keputusan dalam riset bisnis ataupun skripsi mahasiswa.

\section{HASIL DAN PEMBAHASAN}

Setelah dilakukan pengujian kekuatan Tarik terhadap komposit Polyester-Pandan wangi didapat data hasil pengujian seperti dalam gambar grafik|4.1 dibawah ini:

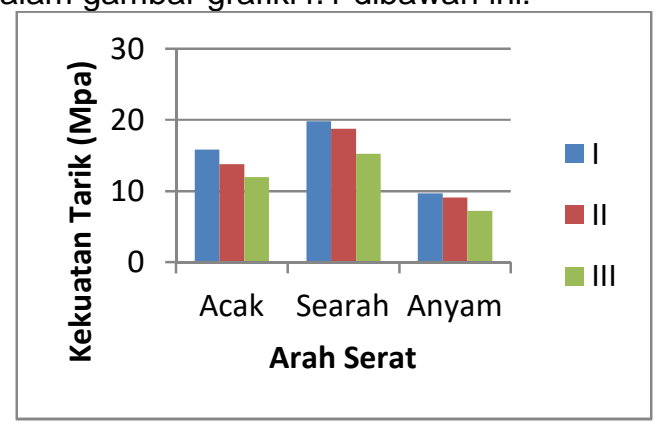

Gambar 4.1.Grafik hubungan antara arah serat dan proses pelubangan dengan kekuatan tarik komposit

Dalam penelitian ini menunjukkan terjadinya peningkatan kekuatan tarik pada material komposit polyester yang diperkuat serat pandan wangi dengan orientasi serat searah, dimana kekuatan tarik tertinggi terdapat pada komposit tahap I yaitu sebesar 27.20 MPa dan kekuatan tarik terendah terdapat pada komposit tahap III yaitu sebesar 13.00 MPa. Pada material komposit dengan orientasi serat acak mengalami penurunan kekuatan tarik sebesar $19.93 \%$ dengan kekuatan tarik tertinggi terdapat pada tahap I yaitu sebesar $17.90 \mathrm{MPa}$ dan kekuatan tarik terendah terdapat pada tahap III sebesar 8.00 
MPa. Dan pada orientasi serat anyam mengalami penurunan kekuatan tarik sebesar $51.09 \%$ dengan kekuatan tarik tertinggi terdapat pada tahap I yaitu sebesar 17.30 $\mathrm{MPa}$ dan kekuatan tarik terendah terdapat pada tahap III sebesar $6.80 \mathrm{MPa}$.

\section{Data Panjang Delaminasi}

Kehadiran lubang ditengah specimen menurunkan kekuatan tarik komposit, karena menyebabkan efek tarik atau sebagai konsentrator tegangan. Pada penelitian ini komposit dilubangi dengan tahap pelubangan I, II dan III, dengan tahap I (berdiameter 2, kemudian diteruskan dengan diameter 4 dan 6 $\mathrm{mm}$ ), tahap II (berdiameter 4 kemudian diteruskan dengan diameter $6 \mathrm{~mm}$ ), dan tahap III (berdiameter $6 \mathrm{~mm}$ ).



\section{Gambar 4.2 Grafik hubungan panjang delaminasi dengan proses pelubangan dan arah serat}

Kegagalan uji tarik komposit polyesterpandan wangi berlubang adalah adanya kerusakan retakan dan delaminasi yang terkonsentrasi disekitar lubang. Delaminasi ini dapat disebabkan karena ikatan antar muka resin unsaturated polyester dengan serat pandan wangi yang kurang baik dan getaran atau gesekan yang terjadi pada saat proses pelubangan.

Dari data dan gambar diatas terlihat jelas bahwa pada proses pelubangan tahap I memiliki panjang daerah delaminasi yang lebih kecil dibandingkan dengan proses pelubangan pada tahap II dan III. Hal ini disebabkan karena pada proses pelubangan tahap I terdapat tiga proses yaitu proses drilling,dan dua proses boring. Adanya proses boring tersebut mempengaruhi laju pemakanan, pada proses pelubangan tahap I digunakan dua proses boring yaitu 4 dan 6 yang bertujuan untuk memperkecil gaya yang dibutuhkan pada proses pelubangan, sehingga laju pemakanan yang dibutuhkan akan lebih kecil. Besarnya laju pemakanan ini mempengaruhi kualitas permukaan hasil lubang.

Pada tahap III hanya ada satu proses yaitu proses drilling, yang mengakibatkan ikatan muka resin dengan serat kurang baik atau daerah pengelupasan pada spesimen disekitar lubang lebih panjang. Sedangkan pada tahap I dan II ada dua proses yaitu proses drilling dan boring. Proses boring tersebut yang bertujuan disamping mengurangi gaya pemakanan juga untuk mengurangi daerah pengelupasan atau delaminasi yang disebabkan oleh proses drilling.

\section{Kesimpulan}

Komposit dengan proses pelubangan tahap I dengan diameter pahat 2, 4 dan $6 \mathrm{~mm}$ memiliki kekuatan tarik tertinggi dan panjang delaminasi terkecil, dan komposit dengan arah serat searah lebih besar kekuatan tariknya dengan nilai 19.77 MPa di bandingkan dengan arah serat acak dngan nilai 15.83 $\mathrm{MPa}$ dan anyam dengan nilai $9.67 \mathrm{MPa}$ yang disebabkan karena arah serat dari arah serat searah tidak berlawanan arah dengan gaya tarik, sehingga penerusan gaya tarik akibat dari uji tarik pada arah serat searah lebih baik dari pada arah serat acak dan anyam.

\section{Saran}

Berdasarkan penelitian yang telah dilakukan maka beberapa saran dapat diberikan guna penelitian selanjutnya yaitu :

Resin polyester setelah dicampur dengan katalis akan cepat mengeras, untuk itulah proses penuangan resin kedalam cetakan harus dilakukan dengan cepat agar resin dapat menyebar merata keserat dalam cetakan sehingga void dalam komposit dapat dikurangi.

\section{DAFTAR PUSTAKA}

Anonim., 2006, Pandan Wangi (Pandanus Amaryllifolius / Pandanus Latifolius) http://inyu.multiply.com/journal/item/6

ASTM 2002, Standard Test Method for Open Hole Tensile Strength of Polymer Matrix Composite Laminates, 5766/D 5766M 
Bilmeyer,F., 1984, Text Book of Polymer Science, New York, Shonwiley and Sons.

DiharjoKuncoro, 2011, Kajian Pengaruh Teknik Pembuatan Lubang Terhadap Kekuatan Tarik Komposit

Diharjo K. \&Triyono T. 2000, Material Teknik, Buku Pegangan Kuliah, UNS Press, Surakarta

Fox Valley Technnical College, 2007, Machine Shop 3 :Milling Machine" Accessories

(http://its.fvtc.edu/machshop3/basicmi II/default.htm)

Feldman.D., dan Hatomo, J.A., 1995, Bahan Polimer Konstruksi Bangunan, Gramedia Pustaka Utama.

George Schneider Jr, Cutting Tool Applications, Prentice Hall

(www.toolingandproduction.com).

Gibson, O. F. (1994) Principle of Composite Materials Mechanics, McGraw-Hill Inc., NewYork, USA

Gibson, R.F., 1994, Principles of Composites Material Mechanics, McGraw Hill Book Co., Singapore, ed., p.p. 115155.
IPTN, 1993, Manual Specification Standard (MSS), Bandung

Justus Kimia Raya. 1996, Technical Data Sheet, Jakarta.

Peijs, Tom., 2002, Composites turn green, Department of Materials, Queen Mary, University of London

Praktikum Proses Manufaktur, 2011, Modul 3 Proses Penggurdian

Schwartz M. 1984, Composite Materials Handbook, McGraw-Hill Inc. NewYork, USA

Setyawan, 2005, Pengaruh Kadar Hardener Terhadap Kekuatan Tarik Komposit Serat Kenaf Poliester, TugasAkhir, F.T.M., U.M.S., Surakarta.

Steve F. and William Oswald J, 1990, Technology of Machine Tools, McGraw-Hill Inc., NewYork, USA

Yuliastomo, 2006, Analisa Karakteristik Komposit Serat Nylon Dengan Matrik Polyester Dengan Sudut Serat 00 dan 900 Metode Sprayed, Tugas Akhir. 